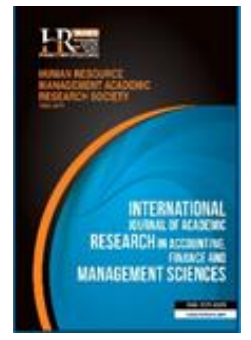

International Journal of Academic Research in Accounting, Finance and Management Sciences

Vol. 8, No. 4, October 2018, pp. 81-89

E-ISSN: 2225-8329, P-ISSN: 2308-0337

(C) 2018 HRMARS

www.hrmars.com

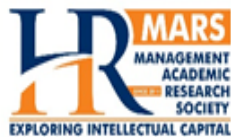

To cite this article: Njimu M., Theuri, M.M., Kiragu D. (2018). Organizational Micro Level Determinants of Sunvival of Youth Owned Micro and Small Enterprises in Nyeri County, Kenya, International Journal of Academic Research in Accounting, Finance and Management Sciences 8 (4): 81-89.

\title{
Organizational Micro Level Determinants of Survival of Youth Owned Micro and Small Enterprises in Nyeri County, Kenya
}

\author{
Monicah Njimu' ${ }^{1}$, M. M. Theuri², David Kiragu ${ }^{3}$ \\ 1,2,3School of Business Management and Economics, Dedan Kimathi University of Technology, \\ E-mail : christopher.githinji@dkut.ac.ke
}

\begin{abstract}
Despite all the investments made by various players, youth owned MSEs have not succeeded in getting off the ground and a high failure rate among them has been documented. As a concern to this high failure rate among the youth owned MSEs, the study sought to evaluate the micro level determinants of survival and success of youth owned MSEs. The study adopted descriptive research. The population of the study constituted the entire 98 MSEs in Nyeri South Sub County, Kenya as at 31 st July 2016. Out of the 98 questionnaires that were distributed, 55 were completed and returned accounting for 56\% response rate. Questionnaires were used to collect primary data from the proprietors of the youth owned MSEs. The researcher carried out a pilot study in order to enhance the validity and reliability of the research instruments Cronbach's Alpha Coefficient $(\alpha)$ was applied to determine reliability of the questionnaires. The data was analyzed using descriptive and inferential statistics. The results of descriptive analysis established that micro level determinants affect the survival of youth owned MSEs to a moderate extent; the desire for independence in the entrepreneur affects the survival of his/ her enterprise to a great extent. Risk taking propensity of the entrepreneur, entrepreneur's ability to recognize a business opportunity, demographic characteristics of the entrepreneur and need for achievement in the entrepreneur affects the survival of his/her enterprise to a moderate extent. Regression results indicated that micro level determinants had positive and statistically significant effect on Survival of MSEs. Based on the findings of the study, it is recommended that MSE owners should invest in their knowledge in business operations and acquire business management skills.
\end{abstract}

Key words

Organizational micro level determinants, survival, youth owned micro and small enterprises

Received: 27 Dec $2018 \quad$ C The Authors 2018

Revised: 18 Jan 2019 Published by Human Resource Management Academic Research Society (www.hrmars.com)

Accepted: 25 Jan $2019 \quad$ This article is published under the Creative Commons Attribution (CC BY 4.0) license. Anyone may reproduce, distribute, translate and create derivative works of this article (for both commercial and noncommercial purposes), subject to full attribution to the original publication and authors. The full terms of this license may be seen at: http://creativecommons.org/licences/by/4.0/legalcode

\section{Introduction}

\subsection{Background to the Study}

In Kenya about $48 \%$ of population represents the youth population which is from 15-35 years of age (Wanjohi, 2010). Micro and Small Enterprises are widely recognized as major sources of employment and income in developing countries. If they grow in size, they would contribute to economic growth and poverty reduction among the youth (Wawire and Nafuko, 2010). According to Wanjohi (2010), like the rest of the world, the Kenya government has now embraced entrepreneurship development through formulation of policies favorable to development of small enterprises particularly in the recent years. For instance the Ministry of Youth Affairs (MoYA) established Youth Enterprise Development Fund (YEDF) in the year 2007 as a source of capital for registered youth groups in Kenya to start and/or boost their Micro and 
Small Enterprises. In addition, most commercial banks and financial institutions have also developed Micro and Small Enterprises tailored strategies to give loans to young entrepreneurs in groups or as individuals.

Despite the efforts put in place to spur establishment of youth enterprises, problems still face potential young entrepreneurs with recent statistics showing that three out of five Micro and Small Enterprises in Kenya fail within the first few months of operation. The major challenge the youth owned MSEs face is how to overcome the determinants hindering growth.

\subsection{Statement of the Problem}

Despite various government policies that have been put in place to improve youth businesses, micro and small enterprises in Kenya, especially in Nyeri County tend have low survival rates. According to 1999 National MSE baseline survey, the youth owned businesses account to 47.7 per cent of businesses in the economy. There are a large number of youth in Nyeri County who cannot afford to start and sustain their small scale businesses despite numerous opportunities by County Council of Nyeri to support them. Youth in Nyeri County could easily take the numerous opportunities offered by the county government but few youths are bold enough to do so. This is attributed to various challenges they encounter that lead to low survival rates of their business enterprises (Kabeer, 2008). The findings of the empirical studies revealed that youth owned small business enterprises are known for their low working capital. Siwadi and Mhangami (2011) opined that the businesses have short life span therefore difficult to retain customers. However, from the findings of the empirical studies, it was evident that little was done with regard to micro level and macro level determinants of survival and success of youth owned MSEs in Kenya.

\subsection{General Objective of the Study}

The general objective of the study was to analyze micro level determinants influencing survival of MSEs owned by youth in Nyeri County.

\section{Literature review}

\subsection{Theoretical Review}

The study is founded on the Nieman and Nieuwenhuizen's Theory of Growth of a Firm. This theory analyses the growth of a firm in form of four critical stages that is survival or abort, growth or decline, maturity or rejuvenation and decline. The survival or abort stage has duration of 0-3 years as in the Churchill and Lewis growth model's start up stage. The theory describes this stage as a stage in which MSEs begin operation and are developed to viability or are aborted at an early stage. According to Shafeek (2009) the thrust in this stage is to get enough customers so as to make the business economically viable and this requires the owner or manager to have good marketing skills. As the name of the stage suggests survival is the ability of a youth owned MSE to continue carrying out its operations beyond the first years of existence. Business survival is the ability of a firm to continuously be in operation despite various challenges, that is, the managerial process of directing the affairs of a firm regularly on a going concern basis and meets the needs of all stakeholders (Akindele et al., 2012). The main determinants as to whether the MSE goes beyond the first stage are the micro level determinants such as the proprietor's competence and organizational capabilities.

The second phase is the growth or decline stage which has duration of 4-6 years. According to Shafeek this stage is occasioned by accelerated growth rate and resources are under major pressure. The growth stage is believed by most researchers to be the most dangerous stage in the life cycle of the new SMEs regardless of the sector of operation. This is so because it is when most business failures occur, mostly due to the pressure on resources, hence it is referred to as "Growth or Decline stage" (Nieman and Nieuwenhuizen, 2009). Therefore, it is during this stage that the MSE owner or manager must take heed by keeping a close eye on new entries into the market to avoid pre-mature decline.

The third stage which is the maturity and rejuvenation has a period of 6-9years. The maturity stage is a stage characterized by stability which comes after the rapid growth and expansion of the business in the previous stage together with the increase in competition (Churchill and Lewis 1983). This stage is the one that will either drive the firm onward to a higher level of profitability or censure it to decline and failure. This responsibility is highly dependent on the actions of the owner or manager (Shafeek 2009). The fourth 
stage of the growth of a firm according to the theory is the decline stage. The theory postulates that that firm failure may occur a number of times during the stages. Greiner (1972) noted that the owner or manager might not even realize the stage the firm is going through or even consciously think what they ought to be doing.

\subsection{Micro Level Determinants and Survival of Youth Owned MSE}

The micro level determinants of survival of an MSE refer to the attributes of the MSE proprietor that may affect the survival of an MSE. According to the Trait theory, individuals always have the personality traits to determine which action should be taking. Under the content of entrepreneurship, personal characteristics or traits became focused of many researchers that make distinguish entrepreneurs from the general population (Low and MacMillan, 1988). According to Bergmann and Sternberg (2007), some specific age can be representative of person maturity in making decision to become an entrepreneur. To be specific of the particular age, Ritsilä (2002) stated that the age of 26 to 40 can be considered a period of readiness the choice of occupation. He feels that people at these ages are possibilities to come success. However, as Parker (2004) stated age can positive correlation if its connected with the professional experience, selfreliance, availability of capital increase. Previous researchers have found the gender differences are not significant with business start-ups (Williams, 2004).

Researchers such as Aldrich and Martinez (2001) have found that knowledge and information are basic elements for initial self-confidence of individuals in an entrepreneur venture. With sufficient knowledge, transferring idea into an organization can make entrepreneur obtain resources for initiating an enterprise. Attitudes are usually formed by previous experience, it was logical that entrepreneurs who are experienced with entrepreneurial activities in the past would have stronger entrepreneurial attitudes (Harris and Gibson, 2008). Moreover, Harris and Gibson found students who have experience with family business were possible to be an entrepreneur. Students whose family owned a business had a greater sense of achievement, innovation, and personal control as a result of interacting and working within the business. Risk-taking propensity is another psychological characteristic often related to entrepreneur intention of starting a new business venture. In responding to the risks, entrepreneurs always learn how to handle it from their previous mistake attitude, environment, and from other experience (Harrison and Leitch, 2005).

Shane and Venkataraman (2000) in their study suggest two factors implies a person to recognize particular opportunities: a) congruent information from previous and current can affect a person on recognizing a business opportunity, b) the cognitive characteristics are needed to evaluate these opportunities and later make a decision to exploit them. Every person has different abilities to recognize specific opportunities; it does depend on availability of information. Availability of information defines mental structure, which provides process of recognizing new information. To recognize an opportunity, every entrepreneur should congruent with previous information and new information. Under cognitive science, Researchers pointed people always combine existing concept and information into new ideas based on their ability. Hand et al. (1987) discussed variables thought to be related to business performance, such as characteristics of the entrepreneur (age, education, experience, willingness to work, and ability to deal with customers and employees). Also discussed were the planning abilities of the entrepreneur. Chaganti and Chaganti (1983) indicated that key success factors were innovation, creativity, and managerial competence, which are characteristics found in owners/entrepreneurs. Keats and Bracker (1988) found that success factors are a part of an organization's general environment, task environment, or characteristics of the business owner.

Some researchers such as Lee (1997) found person decides to become an entrepreneur are because they want to be independence and not to work for other (Lee, 1997). These studies showed the basic difference between the role of a person become entrepreneur and a person working for others. McClelland (1967) pointed out that achievement motivation is an important factor provides some light to the entrepreneurship mindset and challenges, especially for the motivational disposition of the entrepreneurs. A person has characteristics of high need for achievement that appreciates and willing to take responsibility, prefers solving problem without any assistance, taking risk, and respects all outcomes of their own decision (Sesen, 2013). Under the personal characteristic theory, locus of control has been one of the focus studies. Locus of control is a complex individual phenomenon which has concerned with 
determining the effects of the perception of an individual to control all events that implies to their lives. Chawla et al. (1997) found that "owner experience and industry trend are not critical to the success of a manufacturing/construction firm in the early stages of the life cycle. Comparing retail firms to manufacturing/construction firms in the same stage of the life cycle, differences were found in the importance of the owner's experience, market knowledge, industry trend, location issues, and purchasing/inventory control". Location issues were more critical to success for retail firms both during early and late stages of the life cycle. Purchasing/inventory control also was critical for retail firms in both the early and later stages.

According to Zetlin (1994), small business owners feel that having a good product is most important, however, other means of achieving success include a commitment to quality and to the customer, innovation in marketing, being flexible when change is needed, maintaining good supplier/customer relationships, and hiring good people that can be empowered. Bird (1989) stated that firms where owners showed innovation, risk-taking, and had previous training were most successful. Another study dealing with characteristics of the owner was by Duchesneau and Gartner (1990). They found that the characteristics of the owner or manager, the strategy of the firm, and the way the business approached start-up were most important to success. Prior experience, long working hours, good communication skills, customer service, planning, flexible management, and risk reduction were other factors cited. Hills and Narayana (1990) also found a myriad of factors that were possible contributors to success. These included customer treatment, good products, management practices, good treatment of employees, and a good reputation for the company. O'Neill and Duker (1986) indicated that small businesses that were successful had higher quality products, lower levels of debt, and lower capital intensity, as well as, relied on the good advice of their accountants.

Cooper et al. (1989) looked at demographic factors, such as age, gender, and race, and found that older, nonminority; male entrepreneurs with four or more years of college were usually associated with successful firms. A study by Bates and Nucci (1989) confirmed that the age and size of the firm had an impact upon survival. The older the firm, the more likely it was to remain in business, and the larger the firm, the more likely it was to be successful. Boyle and Desai (1991) also pointed out that statistics have shown that the longer a small business has been in operation, the better the chance that it will stay in business. Success breeds success. Mintzberg (1994) stated that small business owners must be able to define the required strategies to find success as they continue to change within their organizations. Castrogiovanni (1996) explored the impact that planning has on the survival or success of firms. Preplanning was specifically investigated using three environmental conditions, which were uncertainty, munificence, and industry maturity. He also investigated two founding conditions, knowledge and capital. Findings included a negative relationship between uncertainty and the survival of new businesses. Munificence (abundance of demand) was positively related to survival, while industry maturity had mixed effects on the degree of planning and survival. Pre-existing founder knowledge was found to be positively related to survival, while capital reduced incentives to plan and, thus, was likely to negatively impact planning.

Bates (1995) conducted a study of survival rates among franchise and independent small firms, and found that for the period 1984-1987, the survival rate was much higher for independent firms, as opposed to franchise businesses. The study also stated that while existing studies identifying traits leading to longterm success of small businesses are not incorrect, small firms should not enter markets that are saturated; which would lead to the assumption that knowledge of the market is most important. In 1990, Bates indicated that a firm's likelihood for success was increased if owners were educated, and if an adequate resource investment was made at start-up. In a study by Lussier and Corman (1995), it was noted that successful firms used better professional advisors than did no successful ones, and it made a significant difference if their parents owned a business. However, the authors were unable to find a reliable set of variables to firmly distinguish success from failure. Variables used in the study included capital, recordkeeping and financial control, industry experience, planning, professional advisors, education, staffing, product/service timing, economic timing, age, partners, parents, minority owners, and marketing. Various other studies have used one or several of these to identify critical success factors. 


\subsection{Conceptual Framework}

As summarized in the study of related literature, it is evident that there are some determinants that may ensure survival of youth owned MSEs. The literature has further highlighted the capacities that need to be developed in the youth in order to prepare them adequately to put in place measures that ensure survival of their enterprises. Thus, the conceptualized framework depicts the relationship between micro economic determinants and Survival of MSEs.

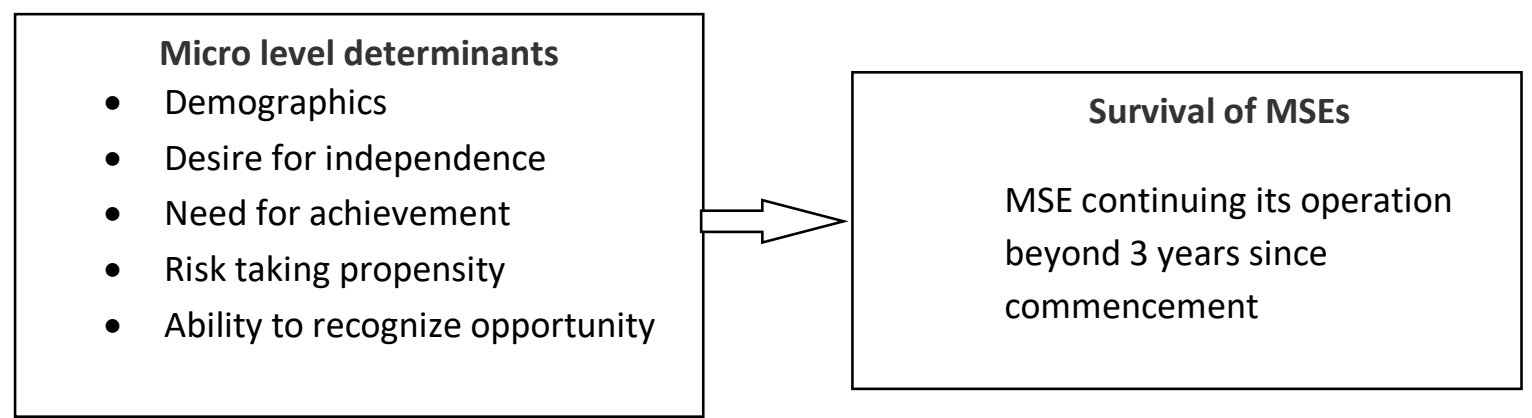

Figure 1. Conceptual Framework

\section{Methodology of research}

The study adopted descriptive research design. According to Kothari (2004) research design refers to the way the study is designed, that is, the method used to carry out a research. It is the investigation in which data is collected and analyzed in order to describe the specific phenomena in its current trends, current events and linkages between different determinants at the current time. This method was deemed appropriate because it describes the relationships between variables in their natural setting without manipulating them. The population of interest in this research consisted of the proprietors of the 98 MSEs from Nyeri South Sub County. . Due to the small number of the MSEs that were licensed at the sub - county level, the study adopted census whereby all the licensed MSEs participated in the study. The study used a questionnaire to collect primary data. The validity and reliability of the instruments was ascertained before actual collection of the data in order to fine tune them. This was done through a pilot study which was conducted in the neighbouring Murang'a County using an identical sample. Cronbach's Alpha Coefficient $(\alpha)$ was applied to determine reliability in which case the instrument was administered twice within duration of two weeks.

The data collected was edited to remove incomplete data, coded and entered into the statistical software. Descriptive statistics such as means and standard deviation were used. Linear regression model was used to derive the relationship between the micro level determinants and the Survival of youth owned MSEs) in the form:

$$
Y=\beta_{0}+\beta_{1} X_{1}+\varepsilon
$$

Where: $Y=$ Survival of MSE

$\mathrm{X}_{1}=$ Micro level characteristics

$\beta_{0}=$ Quantity of $Y$ that is explained by variables not tested in the present study

$\beta_{1}=$ coefficients denoting relative contribution of micro level determinants

$\varepsilon=$ term denoting error

\section{Findings and discussions}

Out of the 98 questionnaires that were distributed, 55 completed questionnaires were completed and collected by the researcher representing a response rate of $56 \%$. According to Edward, $\mathrm{J}$ and Sommer, H. (2000) a response rate of $50-80 \%$ is quite satisfactory.

\subsection{Ages of the Respondents}

Majority of the respondents (49\%) were aged between 31 and 35 years, 35\% were aged $26-30$ years and $16 \%$ were aged between $18-25$ years. The findings indicate that all the respondents were youths. 


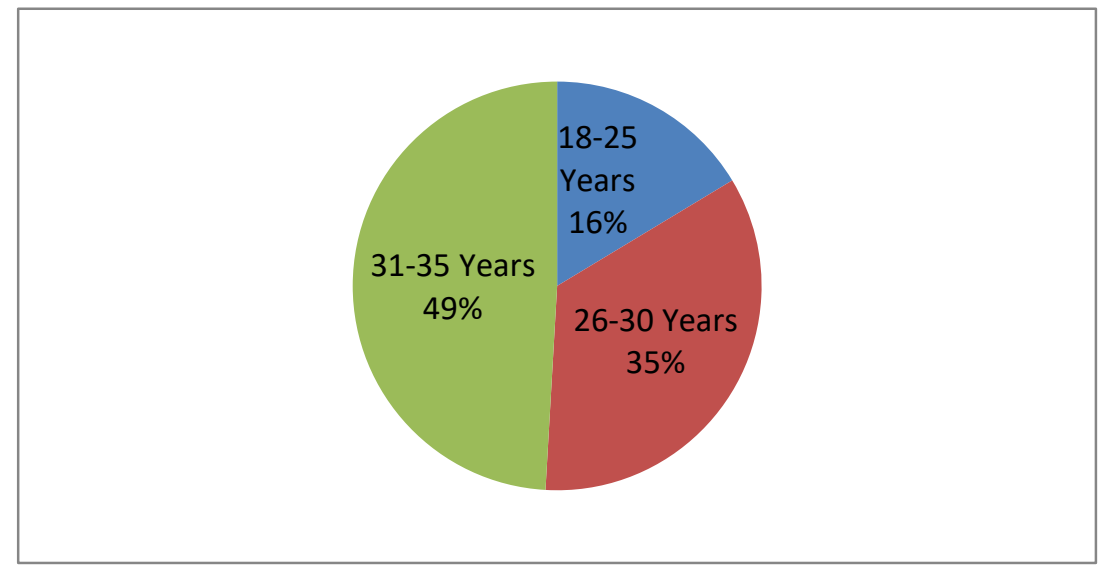

Figure 2. Distribution of the Sample by Age

\subsection{Length of Existence}

Similarly, the assessment of the MSEs by the number of years of existence was done. The results as presented in Table 1 shows that majority of the MSE 21(38\%) represented had been in existence for a period of less than 1 year, 19(35\%) had been in existence for $1-3$ years, $11(20 \%)$ had been in existence for 3-7 years, $3(5 \%)$ for $7-10$ years and only $1(2 \%)$ had been in existence for more than $10 y e a r s$.

Table 1. Distribution of MSEs by Years of Existence

\begin{tabular}{lccc}
\hline & Duration & Number of MSEs & Percentage \\
\hline Less than 1 year & & 21 & 38 \\
1-3 years & & 19 & 35 \\
3-7 years & & 11 & 20 \\
7-10 Years & 3 & 5 \\
More than 10 years & & 1 & 2 \\
\hline & Total & $\mathbf{5 5}$ & $\mathbf{1 0 0}$ \\
\hline
\end{tabular}

The findings indicated that the fewer MSEs continue existing beyond 3 years. This implies that the survival of the MSEs is low.

\subsection{Descriptive Statistic of Micro level Determinants and MSE survival}

In this section, the researcher sought to find out the extent to which micro level determinants influence the survival of youth owned MSEs. The extent was measured on a Likert Scale of 1-5 with the following equivalences: 1- No extent, 2- Small Extent, 3- To a Moderate Extent, 4- To a Great Extent and 5To a very great extent. Mean interpretation was done as follows: 1-1.5: No extent; 1.6-2.5: Small Extent; 2.6-3.5: Moderate Extent; 3.6-4.5: Great Extent and 4.6 - 5.0: Very Great Extent. The results of the study are as shown in Table 2.

Table 2. Micro Level Determinants and MSE's Survival

\begin{tabular}{lcc}
\hline \multicolumn{1}{c}{ Statement of Micro Level Determinants } & Mean & Std.dev. \\
\hline $\begin{array}{l}\text { Demographic characteristics of the entrepreneur such as gender, education level affect the } \\
\text { survival of a the enterprise }\end{array}$ & 3.760 & 1.276 \\
Desire for financial independence has enhanced the survival of the enterprise & 4.050 & 1.239 \\
Need for achievement to see the success of this enterprise has enhanced the survival of this & 3.560 & 1.259 \\
enterprise & 3.800 & 0.890 \\
Being risk averse has ensured the survival of survival of this business enterprise & 3.750 & 1.236 \\
Ability to recognize and take advantage of business opportunities has enhanced the survival of \\
this business enterprise. & $\mathbf{3 . 7 8 4}$ & $\mathbf{1 . 1 8}$ \\
\hline \multicolumn{1}{c}{ Overall Mean } & & \\
\hline
\end{tabular}

The study established that desire for independence in the entrepreneur affects the survival of his/her enterprise to a great extent $(M=4.05, S D=1.239)$. Risk taking propensity of the entrepreneur, entrepreneur's 
ability to recognize a business opportunity, demographic characteristics of the entrepreneur and need for achievement in the entrepreneur affects the survival of the enterprise to a moderate extent. The means ranged between 3.80-3.560. The standard deviations recorded indicate the extent to which the respondents' opinions about the statements on effect of micro level determinants on MSE survival differ. The respondents' differed more on the statement in regard to the effect of micro level determinants on MSE survival $(S D=1.276)$ while they differed less on the effect of risk taking propensity and survival of youth owned MSE $(S D=0.890)$. Overall, the micro level determinants affect survival of youth owned MSES to a moderate extent $(M=3.784, S D=1.18)$.

\subsection{Regression of Micro Level Determinants and MSE survival}

Regression analysis was conducted using Statistical Package for Social Sciences (SPSS) for micro level determinants and MSE survival. Table 3 presents the results obtained.

Table 3. Model Summary for Micro Level Determinants

\begin{tabular}{ccccc}
\hline Model & $\mathbf{R}$ & R Square & Adjusted R Square & Std. Error of the Estimate \\
\hline 1 & $.473^{\mathrm{a}}$ & .224 & .218 & .60707 \\
a. Predictors: (Constant), Micro Level Determinants & & \\
\hline
\end{tabular}

The information presented in Table 3 indicates that independently, micro level determinants predict $22.4 \%$ of the variability in the survival of an MSE. The rest of the variability (77.6\%) can be explained by factors beyond the micro level determinants.

Table 4. ANOVA for Micro Level Determinants

\begin{tabular}{clccccc}
\hline & Model & Sum of Squares & Df & Mean Square & F & Sig. \\
\hline \multirow{2}{*}{1} & Regression & 2.708 & 1 & 2.708 & 5.868 & $.000^{\mathrm{a}}$ \\
& Residual & 39.223 & 54 & .461 & & \\
& Total & 41.931 & 55 & & &
\end{tabular}

a. Predictors: (Constant), Micro Level determinants

b. Dependent Variable: Survival of MSE

The output on Table 4.4 indicates that the $p$-value is small $(p=0.000)$ implying that the relationship between the predictor variable and the dependent variables is statistically significant and the model can be used to predict the dependent variable.

Table 5. Regression Coefficients for Micro Level Determinants

\begin{tabular}{llcccc}
\hline & \multicolumn{2}{c}{ Model } & \multicolumn{2}{c}{ Unstandardized Coefficients } & \multicolumn{2}{c}{ Standardized Coefficients } \\
& B & Std. Error & Beta & Sig. \\
\hline 1 & (Constant) & 1.275 & .213 & & 5.992 \\
& Micro Level Determinants & .219 & .091 & .254 & 2.422 \\
a. Dependent Variable: Survival of an MSE & & & .028 \\
\hline
\end{tabular}

The beta value of 0.219 indicated that the micro level determinants are a predictor of the survival of an MSE. The significant values $(p=0.028)$ under sig. column indicated that the influence of micro level determinants on survival of an MSE was statistical significant. The findings of the study concur with those of other researchers who found a link between the proprietor's characteristics and survival and growth of Micro and Small enterprises. Norzalita and Norjaya (2010) noted that the entrepreneurs' stable and inherent characters influence how they manage their businesses and how successful the businesses become. In addition, they will tend to conduct their business based on the strengths of their specific characteristics. Many aspects have been examined regarding the characteristics of entrepreneurs, such age, motivation, experience, educational background, risk-taking propensity, and preference for innovation.

\section{Conclusions and recommendations}

The study established that micro level determinants affect the survival of youth owned MSEs to a moderate extent. The study established that desire for independence in the entrepreneur affects the 
survival of the enterprise to a great extent. Risk taking propensity of the entrepreneur, entrepreneur's ability to recognize a business opportunity, demographic characteristics of the entrepreneur and need for achievement in the entrepreneur affects the survival of the enterprise to a moderate extent.

In order for youth owned MSEs in Kenya to survive and become sustainable, MSE owners should invest in their own business education, the education of their employees regarding business operations. Awareness about taxation, investments, and business markets among others would enhance MSE sustainability. Some of these areas include enhancing interpersonal and intrapersonal skills by MSE business owners. Secondly, MSE business owners should enhance their business education so as to understand the intricate operations of business and gain business management skills.

\section{Future research}

Arising from this study, the following directions for future research should be carried out. This research only covered micro and small enterprises in Nyeri South Sub County. However, there are other enterprises that are medium and large firms in the same town. Researchers are encouraged to research on them. In future, other MSEs in other towns should be involved to enable the researcher to make adequate conclusions.

\section{References}

1. Akindele, E., Baah-Nuakoh, A., Duggleby, T., Hettige, H., \& Steel, W.F. (2012). Supply and Demand for Finance of Small Scale Enterprises, Discussion Paper No.251. Washington DC: World Bank.

2. Aldrich, H. E. and Martinez, M. A. (2001). Many are called, but few are chosen: An evolutionary perspective for the study of entrepreneurship. Entrepreneurship theory and practice 25(4): 41-56.

3. Bates and Nucci (1989) Towards the Improvement of Entrepreneurship Education in Africa. Paper Boston: McGraw-hill.

4. Bergmann, H., \& Marks, R. (1996). The changing face of entrepreneurship in Germany. Small Business Economics, 28(2-3), 205-221.

5. Bird, B. (1989). Implementing entrepreneurial ideas: The case for intention. Academy of management Review, 13(3): 442-453.

6. Boyle, R., and H. Desai. (1991). Turnaround strategies for small firms. Journal of Small Business Management, 29(3), 33-42.

7. Castrogiovanni (1996), Success in electronic commerce implementation: a cross-country study of small and medium sized enterprises, Journal of Enterprise Information Management, Vol. 21 No. 5, pp. 46892.Durham University, UK, September 2001

8. Chaganti and Chaganti (1983). Founder competence, the environment, and venture performance, Entrepreneurship Theory and Practice, 18: 77-89.

9. Chawla, Pullig, and Alexander (1997). The entrepreneurial personality: a review and some theoretical developments, in J. Curran, J. Stanworth and D. Watkins (Eds) The Survivalof the Small Firm, Vol.1: The Economics of Survival and Entrepreneurship, Aldershot: Gower, pp. 102-119.

10.Churchill and Lewis (1983) Essentials of Economic Theory (reprinted in 1968), New York.

11.Duchesneau and Gartner (1990) Imagination and the Nature of Choice, Edinburgh: Edinburgh University Press.

12. Harris, M. L. and Gibson, S. G. (2008). Examining the entrepreneurial attitudes of US business students. Education+ Training, 50(7): 568-581.

13.Harrison, R.T. and Leitch, C.M. (2005). Entrepreneurial learning: researching the interface between learning and the entrepreneurial context. Entrepreneurship theory and practice, 29(4): 351-371.

14. Hills and Narayana (1990). Examining the entrepreneurial attitudes of US business students. Education+ Training, 50(7): 568-581.

15.Kabeer (2008). A Cross Cultural Study of Gender-role orientation and entrepreneurial self-efficacy. International Entrepreneurship and Management Journal, 9(1), 1-20.

16. Keats and Bracker (1998).The policy Environment for Promoting Small and Medium Sized Enterprises in Ghana and Malawi, (Working Paper Series, Paper No 15). Manchester, England: University of Manchester, Department of Finance and Development Research. 
17. Kothari, C.R. (2004). Research Methodology: Methods and Techniques, (2nd Edition), New Delhi, India: New Age International Publishers.

18. Lee, J. (1997), Education for technology readiness: Prospects for developing countries, Journal of Human Development, 2(1), 115-151.

19.Low \& MacMillan (1998). Small Business Management: An Entrepreneurial Emphasis. London: Thomson South Western.

20.Lussier, R., (1995). A nonfinancial business success versus failure prediction model for young firms. Journal of Small Business Management, 33(I), 8-20.

21. McClelland, D.C. (1967). The achieving society. New York: Free Press.

22. Mintzberg, H. (1994). That's not turbulence, it's really opportunity. Planning Review 22(6), 7-9.

23. Nafuko (2010). Enhancing SMEs competitiveness: The strategies to resolve Barriers to information communication technologies adopted by SMEs. A paper presented in 2011 International Conference on Innovation and Growth: University of Botwsana Republic of Kenya, (2006). Economic survey, the Government printer, Nairobi: Survey, Nairobi: Kenya.

24.Nieman and Nieuwenhuizen (2009). Risk-taking: A Managerial Perspective, New York: Russell Sage Foundation.

25.O'Neill and Duker (1986). Gender Equity.In Mullei, E \& Bokea, A. (Eds.). Micro and Small Enterprises in Kenya: Agenda for Improving the Policy Environment. Nairobi: ICEG.

26.Parker (2004). The Essence of Small Business. Prentice Hall International, UK

27.Ritsilä, J., \& Tervo, H. (2002). Effects of unemployment on new firm formation: Micro-level panel data evidence from Finland. Small business economics, 19(1), 31-40.

28.Sesen, H. (2013). Personality or environment? A comprehensive study on the entrepreneurial intentions of university students. Education+ Training, 55(7): 1-1.

29.Shafeek (2009) 'How relevant is an individual difference theory of personality ratings?', Journal of Personality and Social Psychology, 43: 455-485.

30.Sineath, and Howle (1987). The Impact of Financial Capital on Business Performance: A Comparison of Women- and Men-Owned Firms. SSRN Working Paper. May 2009. Accessed 29 March 2017.

31.Siwadi and Mhangami (2011). An investigation into problems facing small-to-medium growth in the Easter Cape: Enhancing the Strategy for developing small "Growth potential". Journal of Economic Development

32.Wanjohi, A.M. (2010). SME policy in Kenya: Issues and efforts in progress. Nairobi. Journal of European Industrial Training, Vol. 31 Iss: 1 pp. $111-115$

33. Wawire, N.H.W. \& Nafukho, F.M. (2010). Determinants affecting the management of women groups' MSEs in Kakamega District, Kenya, Journal of European Industrial Training, Vol. 34 Issue: 2 pp. 128 152.

34. Williams (2004). Work motivation in the context of a globalizing economy. World Business Council for Sustainable Development (2007). Promoting Small and Medium Enterprises for Sustainable Development. Geneva: WBCSD.

35.Zetlin, M. (1994). Off the beaten path: What must new age entrepreneurs do to succeed Management Review, 83(12), 28-31. 